\title{
GYROLITHES AS A MULTIPURPOSE BURROW: AN ETHOLOGIC APPROACH
}

\author{
RENATA G. NETTO \\ PPGeo UNISINOS, Av. Unisinos, 950, 93022-000, São Leopoldo RS, Brazil.nettorg@unisinos.br \\ LUIS A. BUATOIS, MARÍA GABRIELA MÁNGANO \\ Department of Geological Sciences, University of Saskatchewan, 114 Science Place, Saskatoon SK S7N 5E2, Canada. \\ luis.buatois@usask.ca,gabriela.mangano@usask.ca \\ PATRICIA BALISTIERI \\ Faculdades IBES, Rua Pandiá Calógeras, 272, 89010-350, Blumenau SC, Brazil.pbalistieri@yahoo.com.br
}

\begin{abstract}
Spiral burrows perpendicular to the bedding plane are well known in the fossil record and are usually referred to the ichnogenus Gyrolithes. Common in Mesozoic and Cenozoic marginal-marine, brackish-water deposits, the only records of Gyrolithes in Paleozoic rocks are from the Cambrian. In Permian rocks of the Paraná Basin (Rio do Sul and Rio Bonito formations), south Brazil, some short, irregularly spiraled burrows similar to Gyrolithes occur in marginalmarine, brackish-water siltstone and mudstone, closely associated with Thalassinoides, forming a Glossifungites suite. These burrows seem to play the same ethologic role of the corkscrew-shaped burrows that grade into modern Thalassinoides burrow systems. The corkscrew shape of Gyrolithes is assumed to represent a widespread architectural adaptation to deal with extreme salinity fluctuations in Mesozoic and Cenozoic brackish-water environments. However, spirals produced by thalassinidean shrimps in brackish water connected to modern Thalassinoides burrow systems are related to feeding activities. Instead of behavior to avoid extreme salinity fluctuations, the decapod spiral burrows may represent a feeding strategy to exploit organic-rich zones of the substrate in calm and protected environments. The discovery of spiral burrows in Permian marginal-marine stiffgrounds to firmgrounds indicates that this strategy was already adopted by some group of infaunal crustaceans in brackish-water ecosystems during the late Paleozoic.
\end{abstract}

Key words: Gyrolithes, corkscrew-shaped burrows, Paleozoic, brackish-water, ethology, evolutionary paleoecology.

\begin{abstract}
RESUMO - Escavações espirais perpendiculares ao plano de acamamento são bem conhecidas no registro fóssil e normalmente referidas ao icnogênero Gyrolithes. Apesar de comuns em depósitos salobros marginais marinhos do Mesozóico e do Cenozóico, o único registro de Gyrolithes em rochas paleozóicas data do Cambriano. Escavações curtas semelhantes a Gyrolithes, mas formando espirais irregulares, são registradas em siltitos e argilitos permianos da bacia do Paraná (formações Rio do Sul e Rio Bonito), no sul do Brasil, representativas de depósitos salobros marginais marinhos. Tais escavações ocorrem normalmente associadas a Thalassinoides, compondo uma suíte Glossifungites, e, aparentemente, desempenham a mesma função ecológica que os túneis espirais modernos associados a galerias de decápodes talassinídeos (tipo Thalassinoides). A forma espiral de Gyrolithes é assumida, tanto para as ocorrências cenozóicas como as mesozóicas, como uma adaptação arquitetural bem sucedida para suportar flutuações extremas na taxa de salinidade em ambientes salobros. Contudo, túneis espirais produzidos por talassinídeos modernos em águas salobras e conectados a galerias do tipo Thalassinoides parecem estar relacionados à atividade de alimentação. Assim, mais do que uma estratégia para suportar flutuações extremas de salinidade, as escavações espirais de decápodes podem representar uma estratégia de exploração de zonas ricas em conteúdo orgânico, em ambientes calmos e protegidos. A descoberta de escavações espiraladas em rochas permianas representativas de substratos marginais marinhos compactados e/ou firmes sugere que tal estratégia já era adotada por alguns grupos de crustáceos infaunais em ecossistemas salobros desde o final do Paleozóico.
\end{abstract}

Palavras-chave: Gyrolithes, escavações em espiral, Paleozóico, água salobra, etologia, paleoecologia evolutiva.

\section{INTRODUCTION}

Centimetric-scale, vertical to inclined corkscrew-shaped burrows in the fossil record are generally assigned to the ichnogenus Gyrolithes, which is common in Mesozoic and Cenozoic marginal-marine deposits (e.g., Keij, 1965; Gernant, 1972; Ranger \& Pemberton, 1988, 1992; Mayoral \& Muñiz, $1993,1995,1998)$. Gyrolithes is inferred to be produced by decapod crustaceans due to its common interconnection with Ophiomorpha and Thalassinoides or by the presence of scratch marks in the burrow inner wall (Gernant, 1972; Bromley \& Frey, 1974). Aside from a possible Carboniferous example (Devera, 1989), the only evidence of corkscrew burrows in Paleozoic rocks until now was the diminutive Cambrian Gyrolithes polonicus, attributed to worm-like animals (Fedonkin, 1980; Hein et al., 1991; Jensen, 1977; Mayoral \& 
Muñiz, 1998). Powell (1977) showed that the modern capitellid polychaete Notomastus lobatus constructs descending helical burrows and concluded that Gyrolithes actually represents capitellid burrows instead of crustaceans. However, the observation of spiral components in burrow systems produced by modern thalassinidean shrimps (Dworschak \& Rodrigues, 1997) reinforces the prevalent idea among ichnologists of a crustacean trace-maker for Gyrolithes.

There is general agreement (e.g., Wightman et al., 1987; Beynon et al., 1988; Pemberton \& Wightman, 1992; Buatois et al., 2005a) that Gyrolithes represents a permanent dwelling burrow produced chiefly in marginal-marine settings, as originally suggested by Gernant (1972). Considering that a deep infaunal habitat protects the organism against rapid and extreme salinity variations in brackish-water settings (e.g., Sanders et al., 1965; Knox, 1986; Pemberton \& Wightman, 1992), the helical morphology of Gyrolithes has been interpreted to be an adaptation to seek refuge from extreme salinity fluctuations (e.g., Beynon \& Pemberton, 1992; Buatois et al., 2005a). However, there seems to be a link between coiled burrows of modern decapods and organic-rich layers into the substrate (Dworschak \& Rodrigues, 1997), which suggests that corkscrew burrows may represent feeding strategies in addition to a refuge against salinity fluctuations, or even be a multipurpose burrow.

The presence of simple, irregularly coiled burrows in organic-rich Upper Carboniferous-Lower Permian marginalmarine mudstone of the Rio do Sul and Rio Bonito formations (Paraná Basin, southern Brazil) supports this idea. The burrows are invariably associated with Thalassinoides and show similar diameters, supporting a crustacean trace-maker. The aim of this paper is threefold: (i) to document the presence of Gyrolithes-like burrows in Paleozoic brackish-water stiffgrounds to firmgrounds, (ii) to discuss the burrow architecture and the trace-maker behavior, and (iii) to address the paleoecologic significance of Permian coiled burrows within an evolutionary framework.

\section{SEQUENCE-STRATIGRAPHIC AND DEPOSITIONAL SETTING}

Both the Upper Carboniferous-Lower Permian Rio do Sul Formation (Itararé Group) and the Lower Permian Rio Bonito Formation (Guatá Group) represent part of the fill of the Paraná Basin in southern Brazil (Rocha-Campos, 1967; Schneider et al., 1974; Lavina et al., 1985; Aboarrage \& Lopes, 1986; Lavina \& Lopes, 1987; Zálan et al., 1990; Milani et al., 1994; Santos et al., 1996). Six second-order sequences have been recognized in the Paraná Basin (Milani, 1997); the Carboniferous-Lower Triassic sequence contains the deposits analyzed in this paper.

\section{The Rio do Sul Formation}

The glacigenic deposits of the Rio do Sul Formation are widespread in the Santa Catarina State, both in outcrops and in the subsurface (Schneider et al., 1974; Figure 1). However, correlations between surface and subsurface deposits are not straightforward, especially because of the diachronic character and lenticular geometry of the sandstone and diamictite (França \& Potter, 1988, 1991). Marine deposits are dominant, suggesting the existence of an embayment, where alternating transgressive and regressive episodes were controlled by glaciation-deglaciation cycles.

The Gondwanan glacial-postglacial sedimentary succession of the Itararé Group consists of thinly-laminated rhythmite and mudstone, dark gray to black shale, massive siltic-argilaceous matrix diamictite, heterolithic siltstone and sandstone, and fine- to medium-grained sandstone with trough cross-stratification, parallel to subparallel stratification, climbing ripple cross-lamination and wave ripples. Intraclasts and mud drapes are common in the sandy deposits (Balistieri, 2003). Milimetric to metric-scale dropstones are abundant. The Lontras Shale and associated siltstone beds mark the base of the Rio do Sul Formation in the studied area. The facies stacking pattern, the stratigraphic framework, and trace fossil content are summarized in Figure 2.

The Gyrolithes-like specimens from the Itararé Group occur in a 2 m-thick massive siltstone interval near the base of the Rio do Sul Formation in Mafra (northern Santa Catarina State, Figure 1), and are part of a brackish-water trace fossil assemblage together with Thalassinoides isp. (dominant), Diplocraterion isp., Palaeophycus tubularis, P. striatus, and ?Rhizocorallium isp. (Balistieri \& Netto, 2002; Figure 2), representing a Glossifungites suite. The spreite is tiny in Diplocraterion and has not been observed in ?Rhizocorallium. Gyrolithes-like specimens are invariably associated with Thalassinoides. The sharpness of burrow boundaries in all ichnotaxa, the scratches in the burrow walls of P. striatus, the limited development of spreiten in Diplocraterion, the absence of spreiten in ?Rhizocorallium, and the passive burrow infill with material from the overlying bed are diagnostic of burrowing activity in firmgrounds. The occurrence of the Glossifungites suite in the basal siltstone interval of Rio do Sul Formation has been linked to a co-planar surface of lowstand erosion and transgressive erosion by Balistieri (2003) (SB/FS of Van Wagoner et al., 1990). The coplanar surface represents the top of the first sedimentation cycle in the Itararé Group in Mafra region. The overlying Lontras Shale marks the beginning of the second sedimentation cycle and represents a major transgressive event.

\section{The Rio Bonito Formation}

Integrated analysis of cores, outcrops, and logs from the northern of Mina do Iruí coal field in Cachoeira do Sul (Rio Grande do Sul State, Figure 1) indicates a depositional evolution from a narrow fluvio-estuarine valley to regionally extensive open-marine environments (Netto, 1998; Buatois et al., 2001a,b, 2005b). The successions representative of the Rio Bonito Formation in the northeast area of the Iruí coal field mostly records sedimentation in fluvial to tide-dominated estuarine environments, and it is present as stacked, unconformity-bounded valley-fill sequences (Figure 3). Lowstand fluvial deposits are non-bioturbated. Estuarine deposits of the transgressive systems tracts comprise tidal 


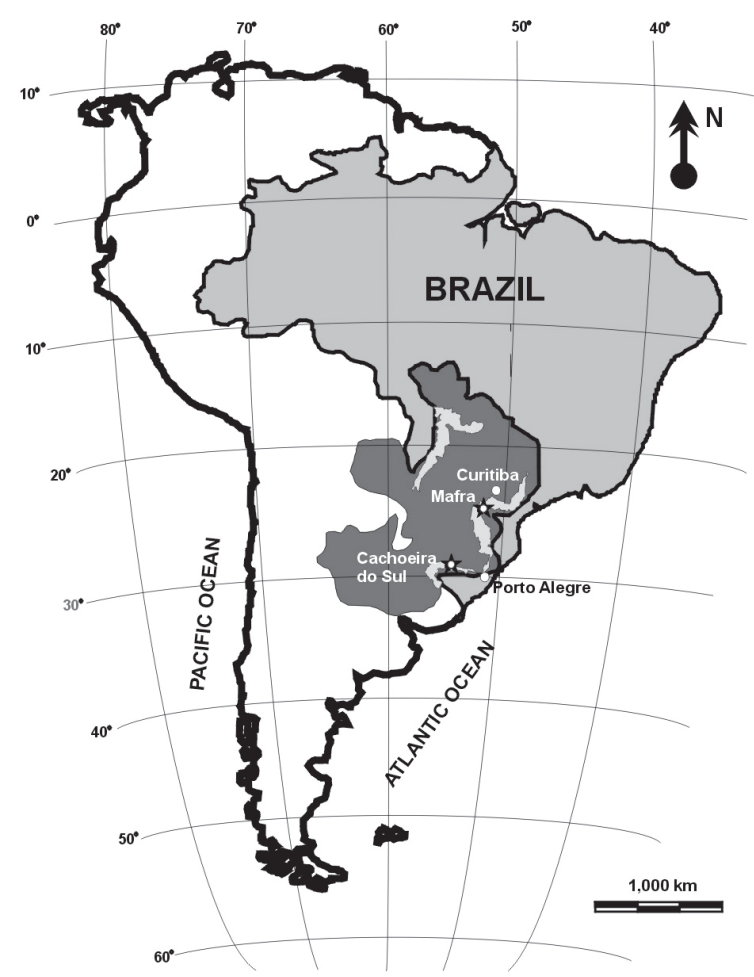

\begin{tabular}{|c|c|c|c|c|}
\hline \multirow{2}{*}{ 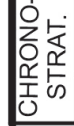 } & \multicolumn{4}{|c|}{ LITHOSTRATIGRAPHY } \\
\hline & & & ANTA CATARINA & RIO GRANDE DO SUL \\
\hline \multirow{4}{*}{ 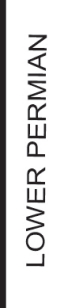 } & \multirow{4}{*}{$\begin{array}{l}0 \\
0 \\
0 \\
\frac{1}{0} \\
0 \\
\mathbb{5} \\
5 \\
5 \\
0\end{array}$} & \multicolumn{2}{|c|}{ PALERMO FORMATION } & PALERMO FM. \\
\hline & & \multirow{3}{*}{ 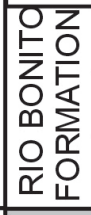 } & SIDERÓPOLIS MB. & \multirow{3}{*}{$\begin{array}{l}\text { RIO BONITO } \\
\text { FORMATION }\end{array}$} \\
\hline & & & PARAGUAÇÚ MB. & \\
\hline & & & TRIUNFO MB. & \\
\hline \multirow{3}{*}{ 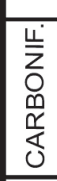 } & \multirow{3}{*}{ 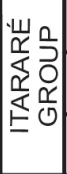 } & \multicolumn{2}{|c|}{ RIO DO SUL FORMATION } & RIO DO SUL FM. \\
\hline & & \multicolumn{2}{|c|}{ MAFRA FORMATION } & \\
\hline & & \multicolumn{2}{|c|}{ CAMPO DO TENENTE FM. } & \\
\hline \multirow{2}{*}{$\begin{array}{l}z \\
\text { 端 }\end{array}$} & \multirow{2}{*}{ 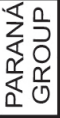 } & \multicolumn{2}{|c|}{ PONTA GROSSA FM. } & \\
\hline & & \multicolumn{2}{|c|}{ FURNAS FM. } & WIIIVIIIIIIIIIIIIIIII \\
\hline & & \multicolumn{3}{|c|}{ PROTEROZOIC BASEMENT } \\
\hline
\end{tabular}

Figure 1. Location map of the Paraná Basin showing the study areas and lithostratigraphic chart the Carboniferous-Lower Permian deposits in Mafra (Santa Catarina State) and Cachoeira do Sul (Rio Grande do Sul State), according to Schneider et al. (1974).

channel and point bar, marsh, and estuary-mouth facies. The estuarine-valley ichnofauna includes Ophiomorpha irregulaire, Skolithos, Planolites, Palaeophycus, Thalassinoides, Rhizocorallium, Lockeia and root traces (Netto, 1994; Buatois et al., 2001a,b, 2005b). The overlying Palermo Formation represents transgressive deposition in open-marine environments (Figure 3). Open-marine strata consist of stacked storm-dominated regional parasequences, and contain Asterosoma, Bergaueria, Chondrites, Cylindrichnus, Diplocraterion, Helminthopsis, Monocraterion, Ophiomorpha, Palaeophycus, Phycosiphon, Planolites, Rhizocorallium, Rosselia, Teichichnus, Thalassinoides, and escape trace fossils of cerianthid anemones and bivalves (Netto, 1994; Buatois et al., 2001a,b, 2005b). Offshore-transition to upper- and loweroffshore deposits are commonly punctuated by transgressive surfaces of erosion demarcated by Glossifungites suites.

The uppermost interval of the Rio Bonito Formation displays features indicative of deposition in a restricted, brackish-water environment. These deposits exhibit an incised basal contact truncating storm-dominated, hummocky crossstratified, lower/middle shoreface deposits that transgressively overlie valley sequences of the Rio Bonito Formation. Towards the south, however, the surface rests directly on estuarine tidal- flat deposits. This surface is locally mantled by a $2.5-3$ $\mathrm{cm}$-thick lag of well sorted medium- to very coarse-grained sand. The surface is interpreted as a co-planar surface of lowstand erosion and transgressive erosion (SB/FS of Van Wagoner et al., 1990) (Figure 4). This uppermost interval of the Rio Bonito Formation locally contains poorly sorted, very coarse-grained sandstone and pebbly sandstone, with abundant mudstone intraclasts and carbonaceous lenses, known to Brazilian geologists as pedra-areia (Gamermann \& Coulon, 1975). These coarse-grained deposits laterally interfinger with, and ultimately pass into, parallel laminated siltstone with synaeresis cracks, interbedded with siderite bands and fine- to very fine-grained sandstone with starved wave ripples and microhummocky cross-stratification. In contrast to the typical fully-marine facies of the Palermo Formation, these basal deposits contain a depauperate ichnofauna suggestive of stressful, brackish-water conditions, which includes Thalassinoides, Gyrolithes-like burrows, Diplocraterion, Teichichnus, and Planolites. This ichnofauna is characterized by simple tiering structures, low degrees of bioturbation, low diversity, and dominance of simple burrows produced by trophic generalists, reflecting adaptations to brackish-water, stressed environments (Buatois et al., 2005a). Fine-grained deposits are punctuated by ravinement surfaces demarcated by the Glossifungites ichnofacies. Specimens similar to Gyrolithes are associated with at least three such surfaces, where they occur together with Thalassinoides (Figure 4). Gyrolithes-like burrows are present in three core wells, namely IC-O7-RS, CA-62-RS and CA-78-RS. Coeval surfaces containing a suite of stiffgound to firmground Thalassinoides were observed in several other wells (Figure 4). This lowermost interval of the Palermo Formation is bounded at the top by a 1 - to 3 -cm thick transgressive lag of moderately sorted, medium- to coarse-grained sand, demarcated by stiffground to firmground Thalassinoides of the Glossifungites suite. This transgressive lag represents a regionally extensive 


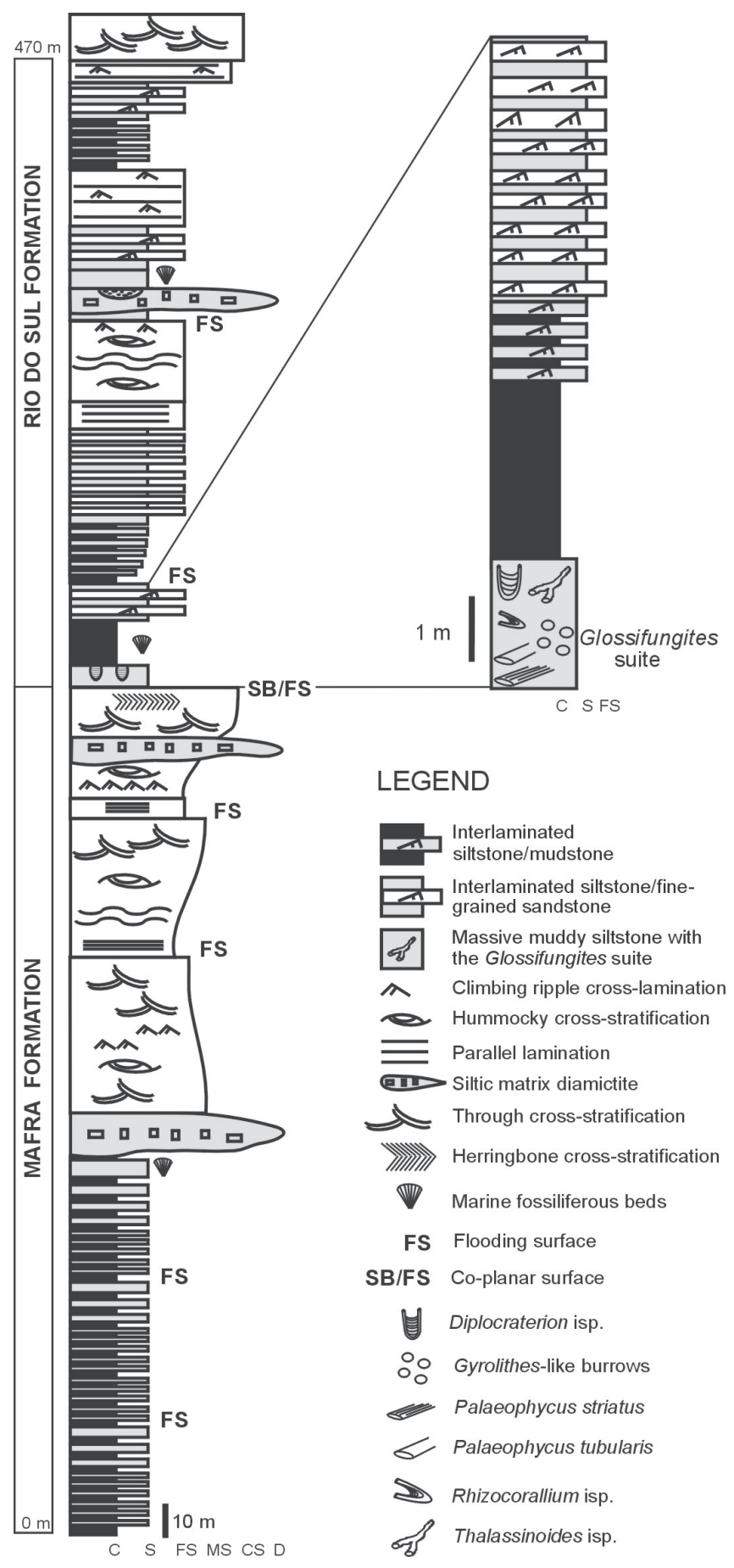

Figure 2. Generalized stratigraphy and depositional setting of the Itararé group in the region of Mafra with a detailed graphic log of the Campo da Lança outcrop, where Gyrolithes-like burrows occur in the Glossifungites suite (modified from Balistieri \& Netto, 2002). Abbreviations: C, clay; CS, coarse-grained sand; D, diamictite; FS, fine-grained sand; MS, medium- grained sand; S, silt.

wave ravinement surface that separates the restricted, brackishwater deposits of Rio Bonito Formation from the open-marine strata that characterize the Palermo Formation. The uppermost interval of the Rio Bonito Formation is attributed to deposition within a brackish-water embayment, specifically a lagoonal complex such as that documented by MacEachern et al. (1998) from the Joffre Field in Alberta.

\section{THE PERMIAN SPIRAL BURROWS}

Description. Short corkscrew-shaped spiral burrows oriented perpendicular to bedding and composed of few, irregularly curved coils (Figures 5A, 6F-G). Tunnel cross-section is subcircular to circular or oval. In core, their morphology is expressed either as offset subcircular to circular cross sections of burrow segments (Figures 5B, 6A-B,E) (cf. Pemberton \& Wightman, 1992, fig. 20) or as a series of inclined to horizontal elongated ovals (Figures 5C, 6C-D) (cf. Ranger \& Pemberton, 1988, fig. 4A-B; Beynon \& Pemberton, 1992, fig. 6A-B). Shaft diameter is $9-13 \mathrm{~mm}$; coil diameter is $24-33$ $\mathrm{mm}$; length is $32-59 \mathrm{~mm}$ (see basic terminology in Gernant, 1972). Burrows are unbranched, sharp-walled, but unlined, locally showing a diagenetic halo. Specimens are preserved as endichnia in organic-rich mudstone and siltstone and are passively filled by well sorted, fine-grained sandstone derived from overlying beds.

Discussion. The described specimens are similar to those recorded by Bromley \& Frey (1974), who revised the original description of the ichnogenus Gyrolithes by Saporta (1884). In the analyzed deposits, Gyrolithes occurs together with sharp-walled, unlined Thalassinoides with equivalent shaft diameter. This close association allows linking both galleries to the same trace-maker. Thalassinoides is regarded as a decapod crustacean burrow, being produced by thalassinidean crustaceans in modern marine environments (Bromley, 1996). Some Thalassinoides show spiraled portions in the gallery, which led Bromley \& Frey (1974) to interpret that Gyrolithes, Ophiomorpha, and Thalassinoides were different parts of the same burrow system.

Although the radiation of thalassinidean decapods took place during the Jurassic (Förster, 1985; Feldmann, 2003), Thalassinoides commonly occurs in Paleozoic rocks (Carmona et al., 2004). Most of Paleozoic Thalassinoides are smaller (shaft diameter commonly $10-15 \mathrm{~mm}$ ) and display a simpler architecture than their Mesozoic-Cenozoic counterparts. In particular, Late Paleozoic specimens may have been produced by other malacostracans, such as stomatopods, reflecting adaptative convergence (Carmona et al., 2004). Like Thalassinoides, the Gyrolithes specimens described in Mesozoic and Cenozoic rocks comprise welldeveloped corkscrew-shaped burrows of several sizes, locally occurring in such abundance that there is almost no space between vertical corkscrews (e.g. specimens from the Pliocene-Pleistocene Cubagua and Tortuga formations in Venezuela, see Estevez et al., 2002). Therefore, the more irregular morphology of Permian Gyrolithes-like burrows parallels the trend displayed by Thalassinoides. The Gyrolithes-like specimens in the Lower Permian deposits of Rio do Sul and Rio Bonito formations occur invariably as part of stiffground to firmground suites, representing the Glossifungites ichnofacies (Frey \& Seilacher, 1980; Pemberton \& Frey, 1985; MacEachern et al., 1992; Balistieri \& Netto, 2002; Gingras et al., 2001; Carmona et al., 2006). In siliciclastic deposits, recognition of substrate-controlled ichnofacies, particularly the Glossifungites ichnofacies, is useful to 


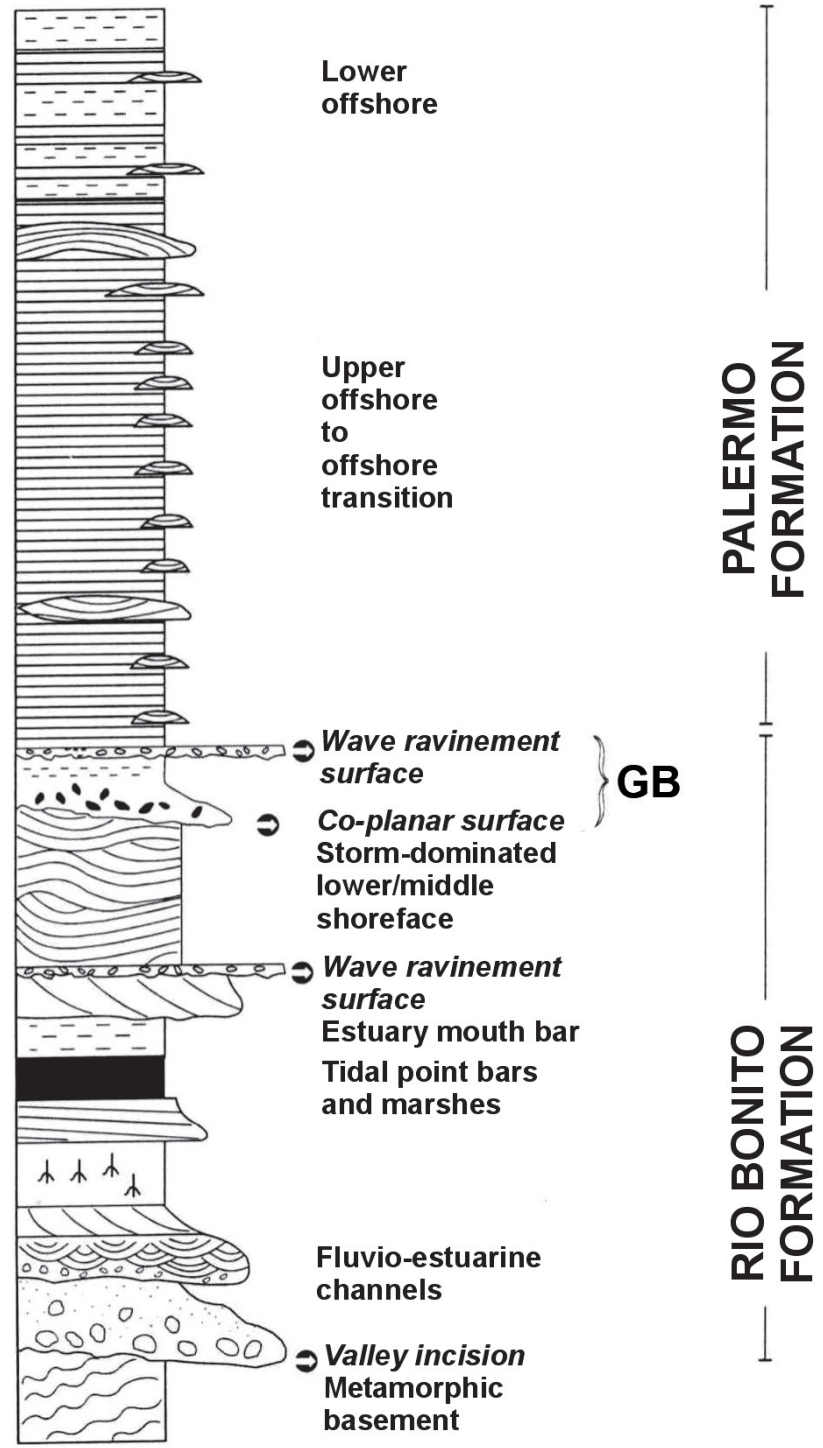

Figure 3. Generalized stratigraphy and depositional setting of the Rio Bonito and Palermo formations in the region of Cachoeira do Sul. GB, Gyrolithes-like burrow-bearing interval.

identify allostratigraphic surfaces, such as ravinement surfaces (MacEachern et al. 1992, 1999; Pemberton et al., 1992; Pemberton \& MacEachern, 1995).

\section{ETHOLOGIC SIGNIFICANCE OF GYROLITHES}

There is general agreement that Gyrolithes is a deep dwelling burrow common in marginal-marine settings and that its vertical helical morphology represents a specialized burrowing architecture to seek refuge from extreme salinity fluctuations in brackish-water environments (e.g., Beynon \& Pemberton, 1992; Buatois et al., 2005a). Infaunalization is a common survival strategy in harsh environments characterized by extreme salinity fluctuations: The deep infaunal habitat is a refuge from the stressful conditions at the sediment surface (Rhoads, 1975). Because fine sediment slows down the exchange of pore water, the effect of salinity fluctuations is diminished (Sanders et al., 1965). Other spiral ichnotaxa, however, may serve for different purposes and bear various paleoecologic and paleoenvironmental implications. For example, large spirals in continental environments, currently assigned to the ichnogenus Daimonelix, represent dwelling structures of rodents (Voorhies, 1975) or therapsids (Smith, 1987). Relatively small spirals, included in the ichnogenus Helicodromites, are predominantly horizontal and probably produced by polychaetes such as Notomastus (Powell, 1977; Rindsberg, 1992). Helicodromites is common in open-marine environments (Hill, 1985; Baldwin \& McCave, 1999). Coiling in this ichnotaxon may be related to anchoring mechanisms and no adaptation to escape from salinity fluctuation is involved in this case.

The modern laomediid shrimp Axianassa australis sometimes produces spirals identical to Gyrolithes (Dworschak \& Rodrigues, 1997; Felder, 2001). The spiral portion of the A. australis burrow is unlined and irregularly coiled. The distance between consecutive whorls is inconsistent, and alternation between dextral and sinistral coiling is common. Locally, turnover involving either a Uturn or a swollen "elbow" occurs. The shaft diameter of $A$. australis spirals is more or less constant, but the width and length are variable. This vertical corkscrew-shaped burrow component connects with horizontal dichotomically branching tunnels analogue to Thalassinoides.

Five of the six known species of Axianassa inhabit intertidal zones, near mangrove areas (mud flats and channels); only one species lives in deep-marine settings (Dworschak \& Rodrigues, 1997). This environmental distribution of vertically oriented corkscrew-shaped burrows is consistent with the fossil record of Gyrolithes, commonly reported from brackish-water mudstone, siltstone and sandstone (see discussion below). In mud flats and mangrove areas, organicrich sediment is commonly concentrated in fine-grained layers at high tide. These layers are capped by others in which the organic matter content is relatively low (Flemming \& Bartoloma, 1995). Thus, it is expected that the amount of organic matter within the substrate inhabited by $A$. australis varies from level to level.

The deposit-feeder A. australis reworks fine-grained, organic-rich substrates in low-energy environments. It usually excavates in zones where compacted mud occurs at just a few centimeters below the surface (Dworschak \& Rodrigues, 1997; Coelho \& Rodrigues, 2001; Felder, 2001). Because it does not need to prevent the burrow from collapse, lining is unnecessary. Thus, its burrows are unlined, sharpwalled, and passively filled, as is the case of the Permian Gyrolithes-like burrows from the Rio do Sul and Rio Bonito formations. Dworschak \& Rodrigues (1997) tentatively suggested that the spiraled portion of the A. australis burrow system is developed where the animal reaches an organicrich layer. At this level, the animal stops excavating exploratory horizontal or gently inclined dichotomic-branching tunnels and starts to coil down. As with the majority of thalassinidean shrimps, A. australis rarely leaves the burrows, eating inside the galleries, excavating new branches and changing its 


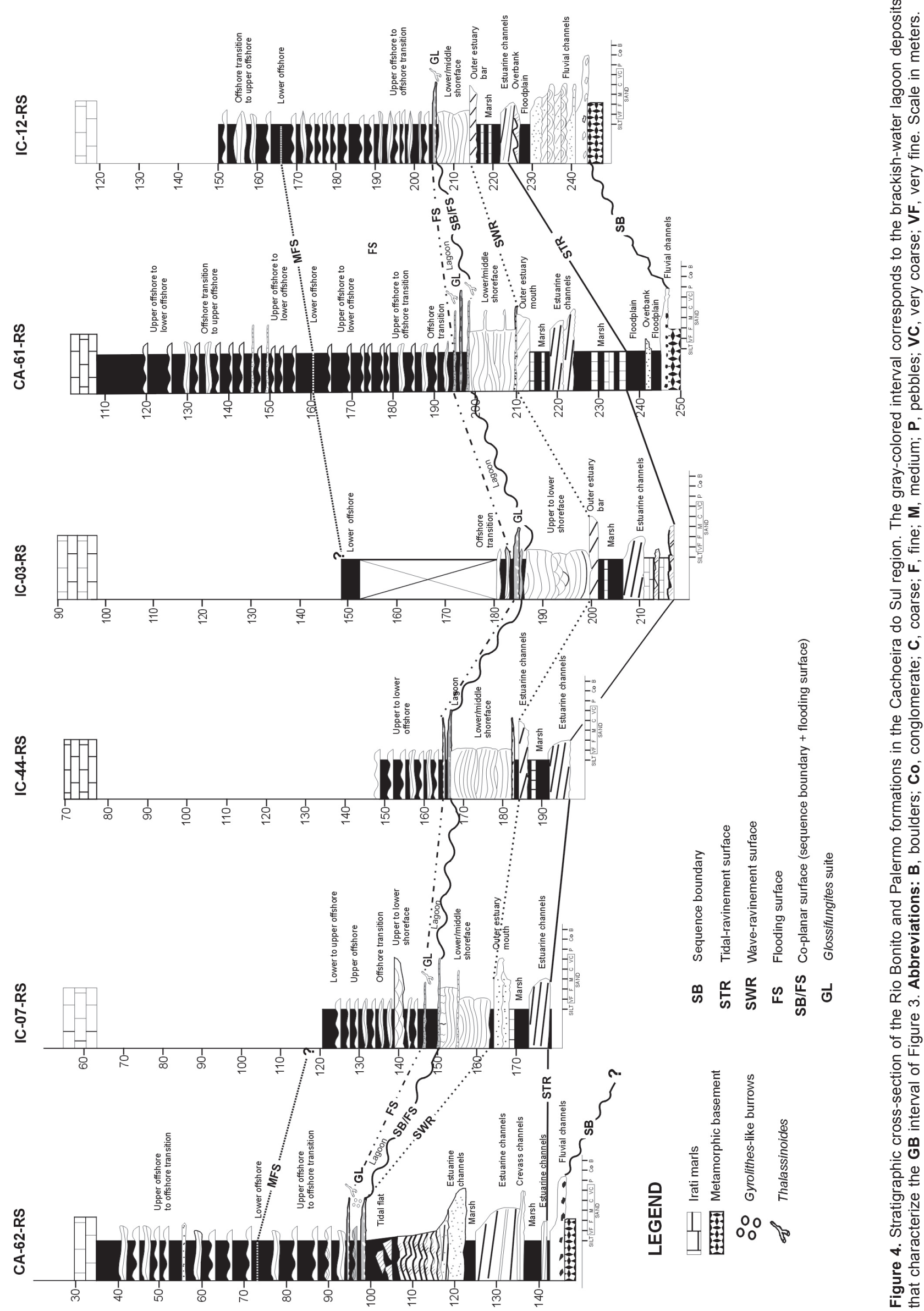


feeding strategy according to food supply. Where the animal reaches substrate levels with unusually organic-rich content, it produces a corkscrew branch, most likely in order to maximize the exploited area, seizing the available food.

Large horizontal spiral burrows attributed to depositfeeders or farmers are commonly observed in deep-sea environments (Bromley, 1996). This burrowing behavior seems to be a strategy to enhance the exploiting area in search for food. Farming has also been pointed as a specialized feeding strategy developed by some deposit-feeding thalassinids (e.g., Griffis \& Suchaneck, 1991; Coelho et al., 2000; Felder, 2001), either by grass debris storage, which favored bacterial growing, or by gardening of the burrow walls to cultivate microorganisms for posterior consumption. Axianassa australis is a good candidate to develop farming behavior because its burrows are commonly associated with red mangrove (Rhizopora mangle L.) zones, "well below the densest concentration of living rootlets in strongly hypoxic and sulfidic muds" (Felder, 2001). Among the several hypotheses raised to explain the function of spiral portions of A. australis burrows, Felder (2001) listed the optimization of burrow wall surface area for microbial lining.

In modern sediments, these spirals are not always perfect corkscrews and may change their loops from right to left in the middle of the burrow course, or they may be composed of 'loose' loops. The coiling diameter is limited by the body size of the animal, and the distance between consecutive whorls is determined by the maximum antero-posterior angle curvature that the animal body can reach (S.A. Rodrigues, personal communication). Smaller angles correspond to closer consecutive whorls and more symmetrical corkscrew-shaped burrows. Although deposit-feeding strategies are uncommon in firmgrounds because highly compacted substrates commonly lack nutritious particles, trace fossils of deposit feeders may be present in low-energy suites of the Glossifungites ichnofacies (e.g. MacEachern \& Burton, 2000).

The general occurrence of Gyrolithes in stiffgrounds and firmgrounds and the preference of the laomeddid shrimps for compacted muds in intertidal and supratidal zones have an additional environmental implication. The compacted nature of the substrate and the richness in organic matter reduce considerably the amount of oxygen into the substrate. In fact, the modern producers of corkscrew burrows similar to Gyrolithes seem to prefer poorly oxygenated substrates in protected environments (Dworschak \& Rodrigues, 1997; Felder, 2001). Therefore, spiral burrows may be representative of dysaerobic substrates in marginal-marine settings.

Felder (2001) suggested that the corkscrew shape Axianassa burrows could be also a strategy against predation. This strategy was suggested by Basan \& Frey (1977) to explain the irregular spirals found in some fiddler crab burrows (Uca spp.). Furthermore, males of some species of ghost crabs (e.g., Ocypode jousseaumei, O. gaudichaudii) construct spiral burrows for courtship (Schober \& Christy, 1993; Clayton, 2005). Thus, corkscrew burrows seem to serve for several different functions, supporting the notion of Gyrolithes as a multipurpose burrow.

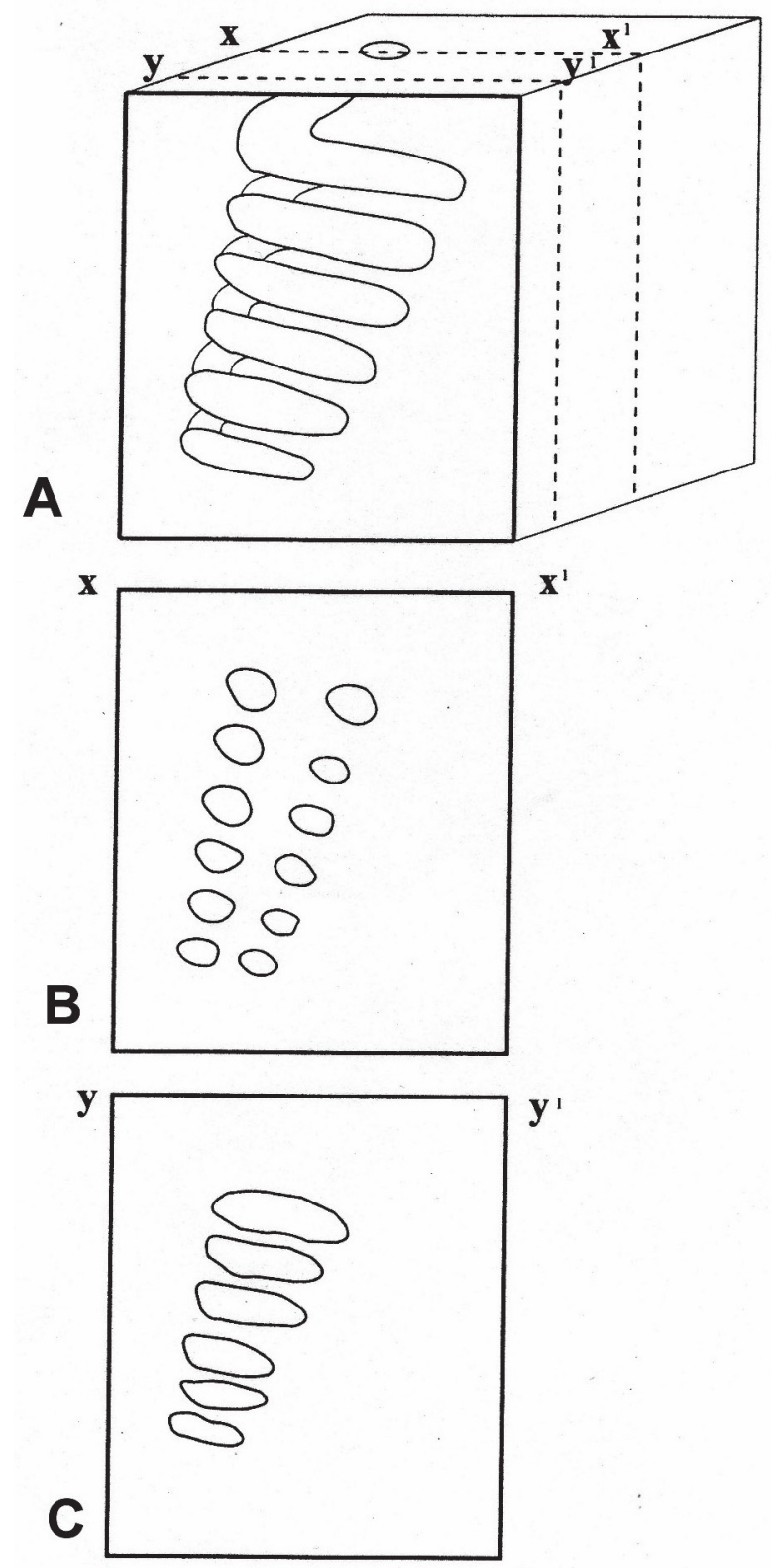

Figure 5. Morphology of the ichnogenus Gyrolithes. A. Reconstruction of general morphology. B-C. Core expression.

\section{PALEOECOLOGIC SIGNIFICANCE OF PERMIAN GYROLITHES-LIKE BURROWS WITHIN AN EVOLUTIONARY FRAMEWORK}

Paleozoic brackish-water ichnofaunas display some differences with respect to post-Paleozoic marginal-marine assemblages. Buatois et al. (2002, 2005a) compared estuarine ichnofaunas from the Pennsylvanian of Kansas and the Cretaceous of Canada, and noted that Pennsylvanian estuarine facies are characterized by lower ichnodiversity, lower degree of bioturbation, scarcity of crustacean burrows, an absence of firmground suites of the Glossifungites ichnofacies, and lack of specific architectural adaptations for coping with extreme salinity fluctuations at the sedimentwater interface. Differences between Pennsylvanian and postPaleozoic brackish-water ichnofaunas were tentatively linked 

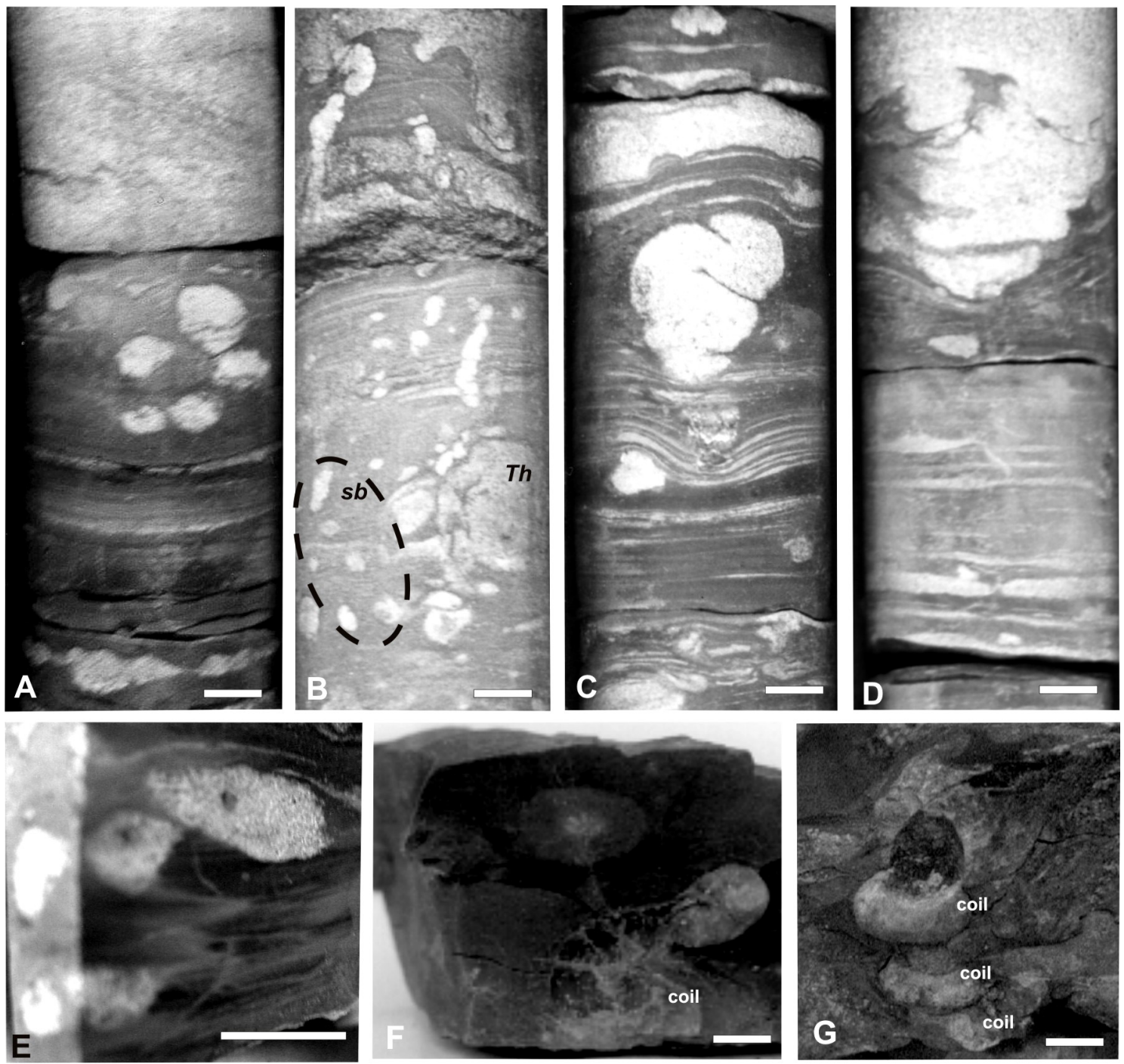

Figure 6. A-D, core expression of Gyrolithes-like burrows from the Lower Permian Rio Bonito Formation, preserved in the core wells CA78-RS (A, C-D) and IC-07-RS (B). The morphology is expressed by offset subcircular to circular cross sections of burrow segments (AB) or by inclined to horizontal elongated ovals (C-D) burrows generally showing sharp boundaries and only two or three spiral whorls; E, inclined view of the sample illustrated in $\mathbf{C}$ showing the cross sections of Gyrolithes-like burrow segments both in the polished inner core face and the curved external face; F-G, Gyrolithes-like burrows from the base of the Rio do Sul Formation (Upper Carboniferous-Lower Permian). Note the irregular pattern of the spiral whorls, varying from incipient, simple coils (E) to short corkscrew-shaped burrows (F). Scale bars $=10 \mathrm{~mm}$.

to evolutionary innovations in Mesozoic estuarine ecosystems, most likely the crustacean radiation and colonization of brackish water soft to firm biotopes.

The ichnogenus Gyrolithes is a common component of brackish-water, estuarine deposits in Cretaceous to Tertiary strata. Occurrences of this ichnogenus in marginal-marine facies have been documented in detail in several basins, including the Cretaceous Western Canadian Sedimentary Basin (Ranger \& Pemberton, 1988, 1992; Beynon \& Pemberton, 1992) and the Miocene to Pliocene Guadalquivir Basin of Spain (Mayoral \& Muñiz, 1993, 1995, 1998). The presence of Gyrolithes-like burrows in brackish-water, valleyfill deposits of the Paraná Basin suggests that a group of infaunal invertebrates developed a similar strategy to deal with the same ecological conditions during the Permian. The occurrence of spiral burrows in Permian and Cretaceous-
Tertiary estuarine valleys represents an example of behavioral convergence. The producer of the Permian burrows is, however, a matter of discussion.

A crustacean origin for Gyrolithes has been suggested by Gernant (1972) and Kennedy (1967), among others. The oldest representatives of Decapoda come from Upper Devonian (Schram et al., 1978) and Lower Carboniferous (Schram \& Mapes, 1984) strata, but are more common since the Permian-Triassic (Glaessner, 1969). In particular, thalassinoid decapods are known since the Jurassic, when crustaceans experienced an evolutionary radiation (Förster, 1985; Feldmann, 2003). However, burrow systems assigned to Thalassinoides are known from early (e.g., Sheehan \& Schiefelbein, 1984; Myrow, 1995) and late (e.g., Archer, 1984) Paleozoic carbonates, while examples of Ophiomorpha have been reported from late Paleozoic siliciclastics (e.g., Driese \& 
Dott, 1984; Chamberlain \& Baer, 1973) (see review by Carmona et al., 2004). Glaessner (1969) noted that one of the oldest occurrences of Mesozoic fossil crustaceans comes from Lower Triassic brackish-water deposits. Brackish-water crustaceans are not known from the Jurassic, but are common in the Cretaceous and Tertiary. Decapod crustaceans are good candidates as producers of late Mesozoic and Cenozoic Gyrolithes, but a decapod origin for late Paleozoic corkscrewshaped spirals is hard to reconcile with the poor Paleozoic record of decapods. However, shrimp-like crustaceans (eocarids) are common in upper Paleozoic marginal- marine, brackish-water deposits (Briggs \& Clarkson, 1990). Burrowing behavior of eocarids is poorly understood, but their lack of chelae, specialized appendages, and calcified cuticles may have been disadvantageous for burrowing in cohesive substrates such as those exhumed during ravinement (Carmona et al., 2004). Stomatopod crustaceans are known since the Carboniferous (Tasch, 1973), but their modern burrows resemble Thalassinoides rather than Gyrolithes (Howard \& Frey, 1975).

Capitellid polychaetes have been documented to produce Gyrolithes-like structures (e.g., Howard \& Frey, 1975; Powell, 1977; Frey \& Wheatcroft, 1989; Buatois et al., 2005a). In modern estuarine systems, spiral burrows are produced by some capitellid, maldanid, and nereid polychaetes, as well as enteropneusts (Gingras et al., 1999), though these are smaller than typical crustacean spirals. Mobile polychaetes are known since the Cambrian (Howell, 1962). Thus, the possibility that late Paleozoic Gyrolithes-like burrows were produced by burrowing polychaetes cannot be disregarded, although the observed close interconnection between these Gyrolithes-like burrows and Thalassinoides points to a common crustacean producer.

Helical burrows are also very common in Cambrian strata (e.g., Fritz, 1980; Fedonkin, 1981, 1983; Liñán, 1984; Crimes \& Anderson, 1985; Hein et al., 1991; Jensen, 1997; Jensen \& Grant, 1998; Stanley \& Feldmann, 1998), generally referred to $G$. polonicus. Compared with younger ichnospecies, G. polonicus is characterized by its small size, and the absence of terminal expansion, scratch marks and carapace impressions (Jensen, 1997). Additionally, Cambrian Gyrolithes are considerably shallower than Mesozoic-Cenozoic representatives. Stanley \& Feldmann (1998) documented annulation in specimens of $G$. polonicus as evidence of peristaltic movements, which suggests an annelid producer. Notably, all Cambrian specimens of Gyrolithes occur in open-marine facies suggestive of normal salinity conditions, which differ from the settings where younger Gyrolithes have commonly been reported, and from the preferential habitat of their modern crustacean analogues.

\section{CONCLUSIONS}

The presence of corkscrew-shaped trace fossils similar to Gyrolithes in Permian marginal-marine deposits suggests that specific burrowing architectures to survive in brackish-water environments represent an adaptive threshold that had been attained during the late Paleozoic. Similar strategies have been commonly recorded in Cretaceous to Tertiary marginal-marine environments, but were previously unknown in Paleozoic brackish-water ecosystems. Additionally, the dominance of crustacean burrows (e.g. Thalassinoides) and the occurrence of firmground suites of the Glossifungites ichnofacies in Lower Permian brackish-water deposits of the Paraná Basin render late Paleozoic and post-Paleozoic brackish-water ichnofaunas more similar. Spiral burrows may have been constructed for exploitation of organic-rich layers within a dysaerobic substrate. Late Mesozoic to Cenozoic Gyrolithes most likely records the evolutionary radiation of decapod crustaceans and their colonization of brackish-water niches, although some groups of polychaetes are also potential trace-makers. The fact that similar structures are present in Lower Permian estuarine deposits suggests the relevance of infaunalization in the colonization of marginal-marine ecosystems. Permian Gyrolithes-like burrows were probably produced by eocarid crustaceans. The occurrence of spiral burrows in Permian and Cretaceous-Tertiary brackish-water deposits represents an example of behavioral convergence. Notably, Permian marginalmarine ichnofaunas show more affinities with Cretaceous to Tertiary brackish-water ichnofaunas than with their Carboniferous counterparts. Comparative analysis of brackishwater ichnofaunas through geologic time provides valuable evidence for understanding the colonization of marginal-marine environments during the course of the Phanerozoic.

\section{ACKNOWLEDGMENTS}

Financial support for this study was provided by FAPERGS (proc. 98/0962.5) and SECYT through a cooperative program between the State of Rio Grande do Sul (Brazil) and Argentina. Additional funds were provided by $\mathrm{CNPq}$ (grants 474345/2003-3 and 304811/2004-1 awarded to RGN), and by Natural Sciences and Engineering Research Council (NSERC, discovery grants 311727-05 and 311726-05 awarded to MGM and LB, respectively). The Brazilian Geological Survey (CPRM) and the Mineral Production National Department (DNPM) provided access to cores, core wells, and geologic data. We thank R. Dias Lima, F. M. W. Tognoli and A. C. Nowatzki for assisting with core descriptions; M. Droser, M. Gingras, and P. Myrow for reviewing early drafts of this manuscript; A. Rindsberg, K. Chamberlain, and an anonymous reviewer for reviewing the paper; and members of the SкоLithos internet discussion group, particularly A. Rindsberg, M. Bertling, and J. de Gibert, for fruitful exchange.

\section{REFERENCES}

Aboarrage, A.M. \& Lopes, R. da C. 1986. Projeto Borda Leste da Bacia do Paraná: integração geológica e avaliação econômica. Ministério das Minas e Energia, Departamento Nacional da Produção Mineral, Porto Alegre, CPRM Sureg/PA, 18 v.

Archer, A.W. 1984. Preservational control of trace-fossil assemblages: Middle Mississippian carbonates of south-central Indiana. Journal of Paleontology, 58:285-297.

Baldwin, C.T. \& McCave, I.N. 1999. Bioturbation in an active deep-sea arc: implications for models of trace fossil tiering. 
Palaios, 14:375-388.

Balistieri, P.R.M.N. 2003. Paleoicnologia da porção superior do Grupo Itararé na região de Mafra (SC): limitações paleoecológicas, paleoambientais e estratigráficas. Tese de Doutorado, Programa de Pós-Graduação em Geologia, Universidade do Vale do Rio dos Sinos, São Leopoldo, 185 p.

Balistieri, P. \& Netto, R.G. 2002. A Glossifungites suite in deposits of the Itararé Group (Upper Carboniferous-Lower Permian of Paraná Basin) at Mafra region, North of Santa Catarina State, Brazil: ichnotaxonomy, and paleoecological and stratigraphical constraints. Acta Geologica Leopoldensia, 55:91-106.

Basan, P.B. \& Frey, R.W. 1977. Actual-paleontology and neoichology of salt marshes near Sapelo Island, Georgia. In: T.P. Crimes \& J.C. Harper (eds.) Trace Fossils 2. Geological Journal Special Issue 9, p. 41-70.

Beynon, B.M. \& Pemberton, S.G. 1992. Icnological signature of a brackish water deposit: an example from the Lower Cretaceous Grand Rapids Formation, Cold Lake Oil Sands area, Alberta. In: S.G. Pemberton (org.) Applications of Ichnology to petroleum exploration, Society of Sedimentary Geologists, p. 199-221.

Beynon, B.M.; Pemberton, S.G.; Bell, D.A. \& Logan, C.A. 1988. Environmental implications of ichnofossils from the Lower Cretaceous Grand Rapids Formation, Cold Lake Oil Sands deposit. In: D.P. James \& D.A. Leckie (eds.) Sequences, stratigraphy, sedimentology: surface and subsurface, Canadian Society of Petroleum Geologists, p. 275-290.

Briggs, D.E.G. \& Clarkson, E.N.K. 1990. The late Palaeozoic radiation of malacostracan crustaceans. In: P.D. Taylor \& G.P. Larwood (eds.) Major evolutionary radiations. Systematics Association Special Volume, 42:165-186.

Bromley, R.G. 1996. Trace fossils - biology, taphonomy and applications. $2^{\text {nd }}$ ed., Chapman and Hall, London, 361 p.

Bromley, R.G. \& Frey, R.W. 1974. Redescription of the trace fossil Gyrolithes and taxonomic evaluation of Thalassinoides, Ophiomorpha and Spongeliomorpha. Bulletin of the Geological Society of Denmark, 23:311-335.

Buatois, L.A.; Gingras, M.K; Maceachern, J.; Mángano, M.G.; Zonneveld, J.-P.; Pemberton, S.G.; Netto, R.G. \& Martin, A.J. 2005a. Colonization of brackish-water systems through time: evidence from the trace-fossil record. Palaios, 20:321-347.

Buatois, L.A.; Mángano, M.G.; Alissa, A. \& Carr, T.R. 2002. Sequence stratigraphic and sedimentologic significance of biogenic structures from a late Paleozoic reservoir, Morrow Sandstone, subsurface of Southwest Kansas, USA. Sedimentary Geology, 152(1): 99-132.

Buatois, L.A.; Netto, R.G. \& Mángano, M.G. $2001 \mathrm{a}$. Reinterpretación paleoambiental de la Formación Rio Bonito (Pérmico de la Cuenca de Paraná, Brasil) en la región del yacimiento de carbón del Iruí, Cachoeira do Sul, RS: integración de análisis de facies, icnología y estratigrafía secuencial de alta resolución. Geogaceta, 29:27-30.

Buatois, L.A.; Netto, R.G. \& Mángano, M.G. 2001 b. Paleoenvironmental and sequence-stratigraphic analysis of Lower Permian marginal- to shallow-marine coal-bearing successions of the Paraná Basin in Rio Grande do Sul, Brazil, based on ichnological data. Ciência-Técnica-Petróleo, Seção Exploração de Petróleo, 20:171-176.

Buatois, L.A.; Netto, R.G. \& Mangano, M.G. 2005b. Ichnology of Permian marginal- to shallow-marine coal-bearing successions: Rio Bonito and Palermo Formations, Paraná Basin, Brazil. In: J.A. MacEachern; K.L. Bann; M.K. Gingras \& S.G. Pemberton (Coords.) Applied Ichnology, Society of Sedimentary Geologists/
American Association of Petroleum Geologists, p. 1-11.

Carmona, N.B.; Buatois, L.A. \& Mángano, M.G. 2004. The trace fossil record of burrowing decapod crustaceans: evaluating evolutionary radiations and behavioural convergence. Fossils and Strata, 51:141-153.

Carmona, N.B.; Ponce, J.J.; Mángano, M.G. \& Buatois, L.A. 2006. Variabilidad de la icnofacies de Glossifungites en el contacto entre las Formaciones Sarmiento (Eoceno medio - Mioceno temprano) y Chenque (Mioceno temprano) en el Golfo San Jorge, Chubut, Argentina. Ameghiniana, 43:413-425.

Chamberlain, C.K. \& Baer, J.L. 1973. Ophiomorpha and a new thalassinid burrow from the Permian of Utah. Brigham Young University Geology Studies, 20:79-94.

Clayton, D. 2005. Substrate (acoustic/vibrational) communication and ecology of the ghost crab Ocypode jousseaumei (Brachyura: Ocypodidae). Marine and Freshwater Behaviour and Physiology, 38(1):53-70.

Coellho, V.R.; Cooper, R.A. \& Rodrigues, S.A. 2000. Burrow morphology and behavior of the mud shrimp Upogebia omissa (Decapoda: Thalassinidea: Upogebiidae). Marine Ecology Progress Series, 200:220-240.

Coelho, V.R. \& Rodrigues S.de A. 2001. Trophic behaviour and functional morphology of the feeding appendages of the laomediid shrimp Axianassa australis (Crustacea: Decapoda: Thalassinidea). Journal of the Marine Biological Association of the United Kingdom, 81(3):441-454.

Crimes, T.P. \& Anderson, M.M. 1985. Trace fossils from late Precambrian- Early Cambrian strata of southeastern Newfoundland (Canada): temporal and environmental implications. Journal of Paleontology, 59:310-343.

Devera, J.A. 1989. Ichnofossil assemblages and associated lithofacies of the Lower Pennsylvanian (Caseyville and Tradewater Formations), southern Illinois. In: J.D. Cobb (coord.) Geology of the Lower Pennsylvanian in Kentucky, Indiana, and Illinois, Illinois Basin Studies, v. 1, p. 57-83.

Driese, S.G. \& Dott, R.H. Jr. 1984. Model for sandstone-carbonate "cyclothems" based on upper member of Morgan Formation (Middle Pennsylvanian) of northern Utah and Colorado. American Association of Petroleum Geologists Bulletin, 68:574597.

Dworschak, P.C. \& Rodrigues, S. de A. 1997. A modern analogue for the trace fossil Gyrolithes: burrows of the thalassinidean shrimp Axianassa australis. Lethaia, 30:41-52.

Estévez, J.; Padrón, V.; Troelstra, S. \& Van Hinte, J. 2002. Late Cenozoic stratigraphy and depositional environment of Araya peninsula, Venezuela. In: EUROPEAN MEETING ON THE PALAEONTOLOGY AND STRATIGRAPHY OF LATIN AMERICA (EMPSLA), 3, 2002. Annales, IRD, Paris, p. 44-47.

Fedonkin, M.A. 1980. Fossil traces of Precambrian Metazoa. Izvestiya Akademii Nauka SSSR, series geologie, 1:39-46.

Fedonkin, M.A. 1981. Belomorskaja biota venda. (The Vendian White-Sea biota). Trudy Akademii Nauk SSSR, 342:1-100.

Fedonkin, M.A. 1983. Besskeletnaya fauna podol'skogo pridnestrov'ya. In: V.A. Velikanov; M.A. Aseeva \& M.A. Fedonkin (eds.) Vend Ukrainy, Naukova Dunka, p. 128-139.

Felder, D.L. 2001. Diversity and ecological significance of deepburrowing macrocrustaceans in coastal tropical waters of the Americas (Decapoda: Thalassinidea). Interciencia, 26(10):440449.

Feldmann, R.M.. 2003. The Decapoda: new initiatives and novel approaches. Journal of Paleontology, 77:1021-1039.

Flemming, B.W. \& Bartoloma, A. 1995. Tidal signatures in modern 
and ancient sediments. Oxford, International Association of Sedimentologists, 368 p. (Special Publication 24).

Förster, R. 1985. Evolutionary trends and ecology of Mesozoic decapod crustaceans. Transactions of the Royal Society of Edinburgh, 76:299-304.

França, A.B. \& Potter, P.E. 1988. Estratigrafia, ambiente deposicional e análise de reservatório do Grupo Itararé (Permocarbonífero), Bacia do Paraná (Parte 1). Boletim de Geociências da Petrobrás, 2(2/4):147-191.

França, A.B. \& Potter, P.E. 1991. Stratigraphy and reservoir potencial of glacial deposits of the Itararé Group (CarboniferousPermian), Paraná Basin, Brazil. American Association of Petroleum Geologists Bulletin, 75:62-85.

Frey, R.W. \& Seilacher, A. 1980. Uniformity in marine invertebrate ichnology. Lethaia, 23:183-207.

Frey, R.W. \& Wheatcroft, R.A. 1989. Organism-substrate relations and their impact on sedimentary petrology. Journal of Geological Education, 37:261-279.

Fritz, W.H. 1980. International Precambrian-Cambrian Boundary Working Group's 1979 field study to Mackenzie Mountains, Northwest Territories, Canada. Geological Survey of Canada Paper, 10(1A):41-45.

Gamermann, N. \& Coulon, F.K. 1975. Estudo do diamictito pedraareia e sua influência na gênese do carvão de mina do Leão (RS). Pesquisas, 5:167-180.

Gernant, R.E. 1972. The paleoenvironmental significance of Gyrolithes (lebensspur). Journal of Paleontology, 46:735-741.

Gingras, M.K.; Pemberton, S.G. \& Saunders, T. 1999. The ichnology of modern and Pleistocene brackish-water deposits at Willapa Bay, Washington: variability in estuarine settings. Palaios, 14:352-374.

Gingras, M.K.; Pemberton, S.G. \& Saunders, T. 2001. Bathymetry, sediment texture, and substrate cohesiveness; the ir impact on modern Glossifungites trace assemblages at Willapa Bay, Washington. Palaeogeography, Palaeoclimatology, Palaeoecology, 169:1-21.

Glaessner, M.F. 1969. Decapoda. In: R.C. Moore (ed.) Treatise on Invertebrate Paleontology, Part R, Arthropoda 4, Geological Society of America and University of Kansas Press, v. 2, p. 400-533.

Griffis, R.B. \& Suchanek, T.H. 1991. A model of burrow architecture and trophic modes in thalassinidean shrimp (Decapoda: Thalassinidea). Marine Ecology Progress Series, 79:171-183.

Hein, F.J.; Robb, G.A.; Wolberg, A.C. \& Longstaffe, F.J. 1991. Facies descriptions and associations in ancient reworked (?transgressive) shelf sandstones: Cambrian and Cretaceous examples. Sedimentology, 38:405-431.

Hill, G.W. 1985. Ichnofacies of a modern size-graded shelf, northwestern Gulf of Mexico. In: H.A. Curran (ed.) Biogenic structures: their use in interpreting depositional environments. Society of Economic Paleontologists and Mineralogists, p. 195-210.

Howard, J.D. \& Frey, R.W. 1975. Regional animal-sediment characteristics of Georgia estuaries. Senckenbergiana Maritima, 7:33-103.

Howell, B.F. 1962. Worms. In: R.C. Moore (ed.) Treatise on Invertebrate Paleontology, Part W, Miscellanea. Geological Society of America and University of Kansas Press, p. 144-177.

Jensen, S. 1997. Trace fossils from the Lower Cambrian Mickwitzia sandstone, south-central Sweden. Fossils and Strata, 42:1-111.

Jensen, S. \& Grant, S.W.F. 1998. Trace fossils from the Divdalen Group, northern Sweden: implications for Early Cambrian biostratigraphy of Baltica. Norsk Geologisk Tidsskrift, 78:305-
317.

Keij, A.J. 1965. Miocene trace fossils from Borneo. Palaeontologische Zeitschrift, 39:220-228.

Kennedy, W.J. 1967. Burrows and surface traces from the Lower Chalk of southern England. Bulletin of the British Museum of Natural History (Geology), 15:127-167.

Knox, G.A. 1986. Estuarine ecosystems: A systems approach, volume 1. Boca Ratón, CRC Press, 289 p.

Lavina, E.L. \& Lopes, R. da C. 1987. A transgressão marinha do Permiano Inferior e a evolução paleogeográfica do Supergripo Tubarão no Estado do Rio Grande do Sul. Paula-Coutiana, 1:51-103.

Lavina, E.L.; Nowatzki, C.H.; Santos, M.A.A. dos \& Leão, H.A. 1985. Ambientes de sedimentação do Supergrupo Tubarão na região de Cachoeira do Sul, RS. Acta Geologica Leopoldensia, 21:5-75.

Liñán, E. 1984. Los icnofósiles de la Formación Torrearboles (¿Precámbrico?-Cámbrico inferior) en los alrededores de fuente de Cantos, Badajoz. Cuadernos do Laboratoria Xeológico de Laxe, 8:47-74.

MacEachern, J.A. \& Burton, J.A. 2000. Firmground Zoophycos in the Lower Cretaceous Viking Formation, Alberta: a distal expression of the Glossifungites ichnofacies. Palaios, 15:387389.

MacEachern, J.A.; Raychaudhuri, I. \& Pemberton, S.G. 1992. Stratigraphic applications of the Glossifungites ichnofacies: delineating discontinuities in the rock record. In: S.G. Pemberton (ed.) Applications of ichnology to petroleum exploration - a core workshop, Society of Economic Paleontologists and Mineralogists, p. 169-198.

MacEachern, J.A.; Zaitlin, B.A. \& Pemberton, S.G. 1998. Highresolution sequence stratigraphy of early transgressive deposits, Viking Formation, Joffre Field, Alberta, Canada. American Association of Petroleum Geologists Bulletin, 82:729-756.

MacEachern, J.A.; Zaitlin, B.A. \& Pemberton, S.G. 1999. A sharpbased sandstone of the Viking Formation, Joffre Field, Alberta, Canada: criteria for recognition of transgressively incised shoreface complexes. Journal of Sedimentary Research, Section $B, 69: 876-892$.

Mayoral, E. \& Muñiz, F. 1993. Consideraciones paleoetológicas acerca de Gyrolithes. In: JORNADAS DE PALEONTOLOGÍA, 9, 1993. Comunicaciones, Barcelona, SPE, p. 18-22.

Mayoral, E. \& Muñiz, F. 1995. Nueva icnoespecie de Gyrolithes del Mioceno Superior de la cuenca de Guadalquivir (Lepe, Huelva). Revista Española de Paleontología, 10:190-201.

Mayoral, E. \& Muñiz, F. 1998. Nuevos datos icnotaxonómicos sobre Gyrolithes del Plioceno Inferior de la cuenca del Guadalquivir (Lepe, Huelva, España). Revista Española de Paleontología, 13:61-69.

Milani, E.J. 1997. Evolução tectono-estratigráfica da Bacia do Paraná e seu relacionamento com a geodinâmica fanerozóica do Gondwana sul-ocidental. Programa de Pós-Graduação em Geociências, Universidade Federal do Rio Grande do Sul, Tese de Doutorado, $255 \mathrm{p}$.

Milani, E.J.; França, A.B. \& Schneider, R.L. 1994. Bacia do Paraná. Boletim de Geociencias da Petrobras, 8(1):69-82.

Myrow, P.M. 1995. Thalassinoides and the enigma of early Paleozoic open-framework burrow systems. Palaios, 10:58-74.

Netto, R.G. 1994. A paleoicnologia como ferramenta de trabalho na seqüencia sedimentar Rio Bonito/Palermo. Programa de PósGraduação em Geociências, Universidade Federal do Rio Grande do Sul, Tese de Doutorado, 272 p. 
Netto, R.G. 1998. Padrão de icnofábricas da sequência sedimentar Rio Bonito/Palermo e seu valor na diagnose paleoambiental. Acta Geologica Leopoldensia, 21:209-225.

Pemberton, S.G. \& Frey, R.W. 1985, The Glossifungites ichnofacies: modern examples from the Georgia coast, U.S.A. In: H.A. Curran (ed.) Biogenic structures: their use in interpreting depositional environments, Society of Economic Paleontologists and Mineralogists, p 237-259.

Pemberton, S.G. \& MacEachern, J.A. 1995. The sequence stratigraphic significance of trace fossils: examples from the Cretaceous foreland basin of Alberta, Canada. In: J.C. Van Wagoner \& G. Bertram (eds.) Sequence stratigraphy of foreland basin deposits - outcrop and subsurface examples from the Cretaceous of North America, American Association of Petroleum Geologists, p. 429-475.

Pemberton, S.G.; MacEachern, J.A. \& Frey, R.W. 1992. Trace fossil facies models: environmental and allostratigraphic significance. In: R.G. Walker \& N.P. James (eds.) Facies models response to sea level changes, Geological Association of Canada, p. 47-72.

Pemberton, S.G. \& Wightman, D.M. 1992. Ichnological characteristics of brackish water deposits. In: S.G. Pemberton (ed.) Applications of ichnology to petroleum exploration - a core workshop. Society of Economic Paleontologists and Mineralogists, p. 141-167.

Powell, E.N. 1977. The relationship of the trace fossil Gyrolithes (=Xenohelix) to the family Capitellidae (Polychaeta). Journal of Paleontology, 51:552-556.

Ranger, M.J. \& Pemberton, S.G. 1988. Marine influence in the McMurray Formation in the Primrose area, Alberta. In: D.P. James \& D.A. Leckie (eds.) Sequences, stratigraphy, sedimentology: surface and subsurface. Canadian Society of Petroleum Geologists, p. 439-450.

Ranger, M.J. \& Pemberton, S.G. 1992. The sedimentology and ichnology of estuarine point bars in the McMurray Formation of the Athabasca Oil Sands Deposit, northeastern Alberta, Canada. In: S.G. Pemberton (ed.) Applications of ichnology to petroleum exploration - a core workshop, Society of Economic Paleontologists and Mineralogists, p. 401-421.

Rhoads, D.C. 1975. The paleoecological and environmental significance of trace fossils. In: R.W. Frey (ed.) The study of trace fossils. Springer, p. 147-160.

Rindsberg, A.K. 1992. Holocene ichnology of eastern Mississippi Sound, Alabama. Geological Survey of Alabama, p. 1-75 (Circular 167).

Rocha-Campos, A.C. 1967. The Tubarão Group in the Brazilian portion of the Paraná Basin. In: J.J. Bigarella; R.D. Becker \& I.D. Pinto (eds.) Problems in Brazilian Gondwana Geology, CNPq, p. 27-102.
Sanders, H.L.; Mangelsdorf, P.C. \& Hampson, G.R. 1965. Salinity and faunal distribution in the Pocasset River, Massachusetts. Limnology and Oceanography, 10(suppl.):R216-R229.

Santos, P.R. dos; Rocha-Campos, A.C. \& Canuto, J.R. 1996. Patterns of late Paleozoic deglaciation in the Paraná Basin, Brazil. Palaeogeography, Palaeoclimatology, Palaeoecology, 125:165-184.

Saporta, G. de. 1884. Les organismes problématiques des anciennes mers. Paris, Masson, 102 p.

Schneider, R.L.; Mülmann, H.; Tommasi, E.; Medeiros, R.A.; Daemon, R.F. \& Nogueira, A.A. 1974. Revisão estratigráfica da Bacia do Paraná. In: CONGRESSO BRASILEIRO DE GEOLOGIA, 18, 1974. Anais, SBG, 1:41-65.

Schober, U.M. \& Christy, J.H. 1993. Sand disposal of the painted ghost crab Ocypode gaudichaudii (Decapoda: Ocypodidae): A possible role in courtship. Marine Biology, 116(1):53-60.

Schram, F.R. \& Mapes, R.H. 1984. Imocaris tuberculata, n. gen., n. sp., (Crustacea Decapoda) from the Upper Mississippian Imo Formation, Arkansas. Transactions of the San Diego Natural History Museum, 20:165-168.

Schram, F.R.; Feldmann, R.M. \& Copeland, M.J. 1978. The Late Devonian Paleaopalaemonidae and the earliest decapod crustaceans. Journal of Paleontology, 52:1375-1387.

Sheehan, P.M. \& Schiefelbein, D.R.J. 1984. The trace fossil Thalassinoides from the Upper Ordovician of the eastern Great Basin: deep burrowing in the early Paleozoic. Journal of Paleontology, 58:440-447.

Smith, R.M.H. 1987. Helical burrow casts of therapsid origin from the Beaufort Group (Permian) of South Africa. Palaeogeography, Palaeoecology, Palaeoclimatology, 60:155-170.

Stanley, T.M. \& Feldmann, R.M. 1998. Significance of nearshore trace- fossil assemblages of the Cambro-Ordovician Deadwood Formation and Aladdin Sandstone, South Dakota. Annals of Carnegie Museum, 67:1-51.

Tasch, P. 1973. Paleobiology of the invertebrates: data retrieval from the fossil record. New York, Wiley \& Sons, 946 p.

Van Wagoner, J.C.; Mitchum, R.M.; Campion, K.M. \& Rahmanian, V.D. 1990. Siliciclastic sequences, stratigraphy in well logs, cores, and outcrops. American Association of Petroleum Geologists, Methods in Exploration Series, 7:1-55.

Voorhies, M.R. 1975. Vertebrate burrows. In: R.W. Frey (ed.) The study of trace fossils, Springer, p. 325-350.

Wightman, D.M.; Pemberton, S.G. \& Singh, C. 1987. Depositional modeling of the Upper Mannville (Lower Cretaceous), central Alberta: implications for the recognition of brackish water deposits. In: R.W. Tillman \& K.J. Weber (eds.) Reservoir Sedimentology, Society of Economic Paleontologists and Mineralogists, p. 189-220.

Zalán, P.V.; Wolff, S.; Conceição, C.J.; Astolfi, A.M.; Vieira, I.S.; Appi, V.T.; Zanotto, O.\& Marques, A. 1991. Tectonics and sedimentation of the Paraná Basin. In: H. Ulbrich \& A.C. Rocha-Campos (eds.) Gondwana Seven Proceedings, IG/USP, p. 83-118. 